\title{
LEVELS OF NITRIC OXIDE METABOLITES IN RATS WITH HEPATOPULMONARY SYNDROME
}

Background. System of nitric oxide (NO), which consists of NO, and its metabolites, is very important for various biological processes. NO is signalling molecules and mediators of intracellular and intercellular interaction that causes relaxation of smooth muscles of blood vessel walls, inhibits platelet aggregation and their adherence, is involved in the transmission of nerve impulses, cell proliferation.

Objective. The aim of our research was to study the content of nitric oxide metabolites in blood serum and bronchoalveolar lavage, to substantiate their role in pathogenesis of hepatopulmonary syndrome in experiment.

Methods. The experiments were performed on 56 outbread male rats, 180-220 g in weight. The first experimental model of hepatopulmonary syndrome (HPS) was made by imposition of double ligature on common bile duct and its further dissection with a scalpel. The second experimental HPS model was made by 8-week intragastric administration of oil solution CCl4 (400 g per $1 \mathrm{~L}), 0.5 \mathrm{ml}$ per $100 \mathrm{~g}$ of body weight on the first day of the experiment, $0.3 \mathrm{ml}$ per $100 \mathrm{~g}$ on the third day of the experiment and then every third day until the end of the experiment $0.3 \mathrm{ml}$ per $100 \mathrm{~g}$. A mixture of corn flour, lard and cholesterol and alcohol solution was added to the standard diet of the rats.

Results. The total content of nitric oxide metabolites in blood serum of the rats of the experimental group No.1 (on the $31^{\text {st }}$ day after the common bile duct ligation) was significantly increased in 3.9 times $(p 1<0,001)$ if compared with the control group №1. In the rats of the $2^{\text {nd }}$ experimental group (with carbon tetrachloride induced cirrhosis) the total content of nitric oxide metabolites in blood serum also significantly increased in 3.1 times $(p 1<0,001)$. Comparison of nitric oxide metabolites content in blood serum and bronchoalveolar lavage, which directly indicated about the processes in lung tissue, was great importance.

Conclusions. So, in rats with experimental hepatopulmonary syndrome activation of nitroxydergic process by significant increase in nitric oxide metabolites in blood serum and bronchoalveolar lavage took place.

KEYWORDS: hepatopulmonary syndrome, nitric oxide metabolites.

\section{Introduction}

System of nitric oxide (NO), which consists of NO, and its metabolites, is very important for various biological processes [2]. NO is signalling molecules and mediators of intracellular and intercellular interaction that causes relaxation of smooth muscles of blood vessel walls, inhibits platelet aggregation and their adherence, is involved in the transmission of nerve impulses, cell proliferation. Cytostatic activity is also presented in NO. Formation of this agent by immunocompetent cells provides protection of body from being infected by bacteria and cancer cells. The researches on participation of

Corresponding author: Inna Krynytska, Department of Clinical and Laboratory Diagnostics, I. Horbachevsky Ternopil State Medical University, 1 Maidan Voli, Ternopil, Ukraine, 46001 Tel.: +3800352254577

E-mail: krynytska@tdmu.edu.ua
NO in the process of apoptosis are very interesting $[1,5,10]$. Contemporary studies on pulmonary disorders are also associated with impaired nitroxidergic dysfunction $[3,7]$.

$\mathrm{NO}$ is a molecule of high reactivity with an effective half-life from 2 to $30 \mathrm{sec}$, which is formed by the enzymatic oxidation of L-arginine under the influence of cytochrome P-450-like hemoproteins - NO-synthase (NOS). There are 3 isoforms of this enzyme, endothelial (eNOS), neuronal (nNOS) or brain and inducible (iNOS) or macrophagal $[4,6]$. As a lipophilic molecule, NO easily diffuses through cell membranes into the neighbouring cells (e.g. from endothelial to myocytes of vessels) where the formed cyclic guanosine monophosphate decreases the level of free calcium and activates the kinase of myosin light chain causing dilatation of vessel [4]. 
Most cytotoxic effects of NO belong to ONOO that is formed in reaction with superoxide. Peroxynitrite is much more active, nitrosates proteins intensively and can be a source of a highly toxic hydroxyl radical in reaction with superoxide anion radical. ONOO- irreversibly inhibits enzymes of respiratory chain nitrosating them and taking iron away. Inhibition of mitochondrial respiration can cause apoptosis [9].

Production of NO by alveoli can influence the hemodynamic and gas exchange in patients with liver cirrhosis. Thus, a direct relationship between alveolar products of NO and hyperdynamic type of circulation was established [12]. Moreover, in experimental liver cirrhosis in rats, hyper-expression of both inducible and constitutional isoforms of NO were observed synthase in alveolar macrophages and lung endothelial cells [22].

The average life span of nitric oxide in the body is a few seconds. Nitric oxide, which did not participate in chemical reactions, is rapidly oxidized to inactive compounds: nitrites and nitrates. These are nitric oxide stable metabolites, which are the method of this compound synthesis intensity evaluation [18].

So, the aim of our research was to study the content of nitric oxide metabolites in blood serum and bronchoalveolar lavage, to substantiate their role in pathogenesis of hepatopulmonary syndrome in experiment.

\section{Material and Methods}

The experiments were performed on 56 outbread male rats, $180-220 \mathrm{~g}$ in weight. During the simulation of the pathology 8 animals died. Thefirstexperimental model of hepatopulmonary syndrome (HPS) was made by imposition of double ligature on common bile duct and its further dissection with a scalpel. [15] In the control group of animals № 1, common bile duct was separated from the tissue, but not dissected. Postoperative wound was sewed up completely in layers. In the $31^{\text {st }}$ day after the surgery the animals were taken out of experiment under thiopental anaesthesia.

The second experimental HPS model was made by 8-week intragastric administration of oil solution $\mathrm{CCl} 4$ ( $400 \mathrm{~g}$ per $1 \mathrm{~L}$ ), $0.5 \mathrm{ml}$ per $100 \mathrm{~g}$ of body weight on the first day of the experiment, $0.3 \mathrm{ml}$ per $100 \mathrm{~g}$ on the third day of the experiment and then every third day until the end of the experiment $0.3 \mathrm{ml}$ per $100 \mathrm{~g}$. A mixture of corn flour, lard and cholesterol and alcohol solution was added to the standard diet of the rats. The control group of animals № 2 was on a standard diet of the vivarium and was administered intragastrically the equivalent amount of olive oil. [21].

Animal care and experiments were performed in accordance with the European Convention for the Protection of Animals Used for Experimental and Other Scientific Purposes [14].

Blood serum and bronchoalveolar lavage (BAL) were the subjects of the research.

Quantitative assessment of NO metabolites content was performed by evaluation of their amount, which included nitrite ions that were previously presented in the sample $\left(\mathrm{NO}_{2}^{-}\right)$and also nitrate ions restored to nitrites $\left(\mathrm{NO}_{3}^{-}\right)$[2]. Recovery was performed using zinc dust in acidic environment. Nitrites with sulphanilic acid underwent a reaction of diazotization, obtained diazotization solution of N-1 - naftyletylendiamin formed azo dye. Optical density of the obtained colour solution was evaluated by spectrophotometry at absorption maximum and wavelength $536 \mathrm{~nm}$.

According to the evaluation results of calibration solutions optical density $(\mathrm{Y})$, calibration straight line was built and regressor was estimated: $Y=A+B X, Y$ is optical density of calibration solutions; $X$ - concentration of calibration solutions, $\mathrm{mmol} / \mathrm{l} ; \mathrm{B}$ - regression coefficient; A - intercept.

The concentration of NO metabolites in the studied sample was estimated by the equation: $\mathrm{X} 1=(\mathrm{Y} 1-\mathrm{A}) / \mathrm{B}, \mathrm{Y} 1$ is optical density of the studied sample.

Statistical analysis of the data received was conducted by standard methods of variation statistics using statistical software package. Results are presented as $(M \pm m), M$ is mean value, $m$ - standard error. Statistical significance of the studied rates was determined by means of paired t-test.

Correlation analysis was performed between the data studied. Linear correlation coefficient ( $r$ ) and its significance (b) appropriately denoted in the tables (correlation matrices) were evaluated. If index $r=0$, link was considered to be lost, range $0-0,3$ evidenced about weak correlation, index interval 0.3-0.7 demonstrated medium link, and interval $0,7-1,0$ proved a significant correlation interaction. The correlation coefficient was significant at $p<0.05$.

\section{Results and Discussion}

The total content of nitric oxide metabolites $\left(\mathrm{NO}_{2}{ }^{-}+\mathrm{NO}_{3}{ }^{-}\right)$are presented in Table 1.

The total content of nitric oxide metabolites in blood serum of the rats of the experimental 
Table 1. Nitric oxide metabolites content in blood serum and bronchoalveolar lavage in rats with experimental hepatopulmonary syndrome $(\mathrm{M} \pm \mathrm{m})$

\begin{tabular}{|l|c|c|c|c|}
\hline \multicolumn{1}{|c|}{ Experimental group } & $\begin{array}{c}\text { Control group } \\
\text { № } 1(\mathrm{n}=12)\end{array}$ & $\begin{array}{c}\text { Experimental } \\
\text { group № } 1 \\
(\mathrm{n}=12)\end{array}$ & $\begin{array}{c}\text { Control group } \\
\text { № 2 } \\
(\mathrm{n}=12)\end{array}$ & $\begin{array}{c}\text { Experimental } \\
\text { group № 2 } \\
(\mathrm{n}=12)\end{array}$ \\
\hline \multicolumn{3}{|c|}{ Blood serum } \\
\hline $\mathrm{NO}_{2}{ }^{-}+\mathrm{NO}_{3}{ }^{-}, \mathrm{mcmol} / \mathrm{L}$ & $36,7 \pm 6,0$ & $\begin{array}{c}143,4 \pm 14,8 \\
\mathrm{p}_{1}<0,001\end{array}$ & $33,4 \pm 4,4$ & $\begin{array}{c}104,2 \pm 9,3 \\
\mathrm{p}_{1}<0,001 \\
\mathrm{p}_{2}<0,05\end{array}$ \\
\hline & BAL & $12,0 \pm 3,2$ & $\begin{array}{c}54,7 \pm 6,9 \\
\mathrm{p}_{1}<0,001 \\
\mathrm{p}_{2}<0,05\end{array}$ \\
\hline
\end{tabular}

Legends:

$\mathrm{p}_{1}$ - significant difference if compared to the control animals;

$\mathrm{p}_{2}$ - significant difference if compared to the affected animals.

group № 1 (on the $31^{\text {st }}$ day after the common bile duct ligation) was significantly increased in 3.9 times $\left(p_{1}<0,001\right)$ if compared with the control group № 1. In the rats of the $2^{\text {nd }}$ experimental group (with carbon tetrachloride induced cirrhosis) the total content of nitric oxide metabolites in blood serum also significantly increased in 3.1 times $\left(p_{1}<0,001\right)$.

Comparison of nitric oxide metabolites content in blood serum and bronchoalveolar lavage, which directly indicated about the processes in lung tissue, was great importance. It was determined that NO production disorders took place unidirectionally towards the oxidative stress flare. Thus, the total content of nitric oxide metabolites in BAL (Table 1) in the rats of the experimental group № 1 also significantly increased in 5,8 times $\left(p_{1}<0,001\right)$, and in the rats of the experimental group № 2 - in 4.5 times $\left(p_{1}<0,001\right)$.

The correlative analysis showed that, in simulation of hepatopulmonary syndrome by common bile duct ligation, total content of nitric oxide metabolites in blood serum had strong positive correlative link with the content of
$\mathrm{NO}_{2}{ }^{-}+\mathrm{NO}_{3}{ }^{-}$in BAL $(r=0,87)(p<0,01)$. In carbon tetrachloride induced cirrhosis (experimental model № 2) the total content of nitric oxide metabolites in blood serum also had a strong positive correlative relationship with the content of $\mathrm{NO}_{2}{ }^{-}+\mathrm{NO}_{3}{ }^{-}$in $\mathrm{BAL}(r=0,84)(p<0.01)$. This evidenced the unidirectionality of changes in nitroxydergic processes in blood and lungs in cases of hepatopulmonary syndrome of the applied models.

Probably, the synthesis of nitric oxide in cases of experimental hepatopulmonary syndrome increased due to the activation of inducible NO-synthase under the influence of proinflammatory cytokines and endotoxins, which caused increase in production of NO by liver Kupffer's cells and alveolar macrophages. Our results coincide with the studies of other authors. M. B. Fallon et al. defined and emphasized the role of NO in experimental model of liver cirrhosis, where overexpression of eNOS by pulmonary vessels caused increase in production of endothelin-1 (ET-1) by cholangiocytes, whereby expression of endothelin receptors type B to ET-1 at pulmonary vessels and

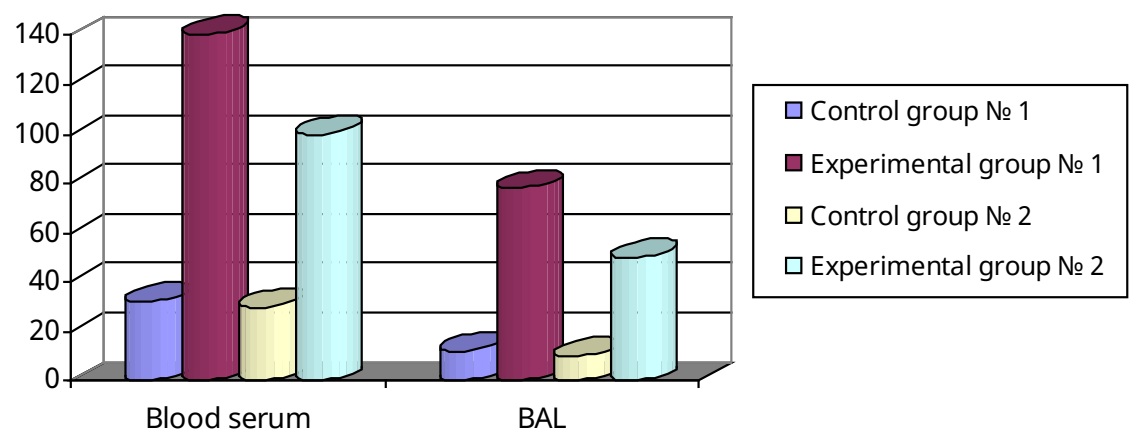

Fig. 1. Comparison of nitric oxide metabolites content in blood serum and bronchoalveolar lavage (* - significant difference if compared to the control animals $(p<0,001) ; *$ - significant difference if compared to the affected animals $(p<0,05)$. 


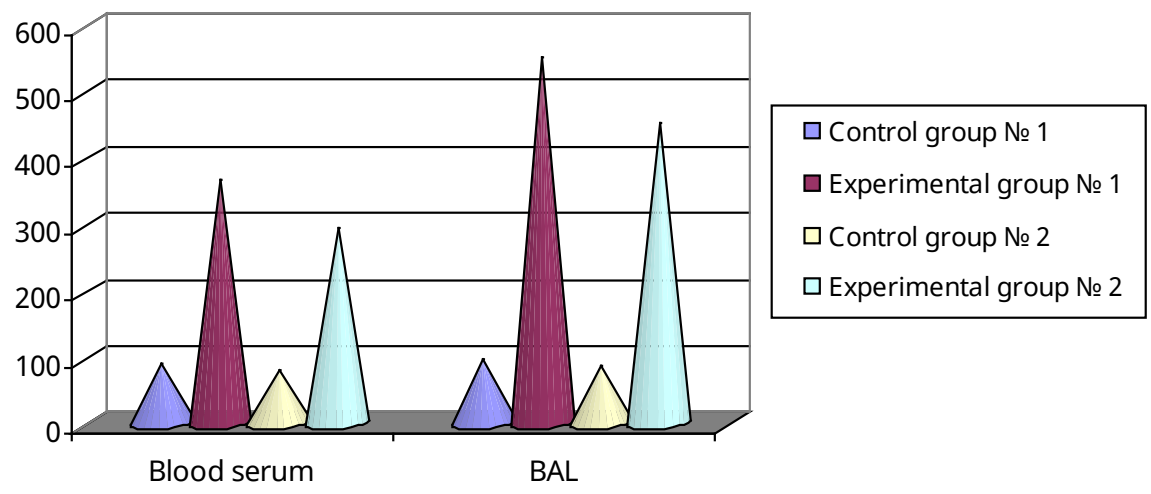

Fig. 2. Comparison of increase in intensity of nitric oxide metabolites content in blood serum and bronchoalveolar lavage $\left(\mathrm{NO}_{2}{ }^{-} \mathrm{NO}_{3}^{-}\right.$content in both control groups was equated to $\left.100 \%\right)$.

synthesis of nitric oxide increased [16]. The level of NO in expired air increased in patients with HPS, and turned to normal in 3-12 months after liver transplantation. [19] Degano B. et al. in a similar study found out that concentration of NO in expired air in patients with liver cirrhosis was 3 times higher than that in the noncancer [12] By means of the method of flow cytofluorimetery that allows to differentiate alveolar and bronchial origin of NO, the main alveolar increase in formation of NO was determined [13]. It was revealed that NO production by alveoli can influence hemodynamic disturbances and changes in gas exchange in patients with liver cirrhosis. Thus, a close relationship between alveolar production of NO and hyperdynamic circulation type was defined [20]. Moreover, in experimental liver cirrhosis in rats, overexpression of both inducible and constitutional isoforms of NO-synthase in alveolar macrophages and lung endothelial cells was observed [22]. The further studies of NO showed that despite all mentioned above, relationship of NO with portal hypertension, hyperdynamic circulation type and degree of liver damage is unclear. [17] In addition, other mo- lecular mechanisms of vasodilation -nitric oxide independent: enzymatic formation of $\mathrm{CO}$ by increase in expression of heme-oxygenase-1, enzymatic formation of $\mathrm{H} 2 \mathrm{~S}$ and stimulation of calcium-activated potassium channels through endothelial derivative - hyperpolarization factor are described in the literature $[8,11]$.

\section{Conclusions and Further Research}

1. So, in rats with experimental hepatopulmonary syndrome activation of nitroxydergic process by significant increase in nitric oxide metabolites in blood serum and bronchoalveolar lavage took place.

2. After studying the results of nitric oxide metabolites content in blood serum and bronchoalveolar lavage, synchronous development of nitroxydergic processes on systemic and local levels and predominance of nitric oxide synthesis in lungs was determined.

In the future, pro-inflammatory cytokines rate in rats with experimental hepatopulmonary syndrome should be studied for more profound pathogenetic substantiation of nitroxydergic processes intensification.

\section{References}

1. Боярчук ОР. Вміст метаболітів оксиду азоту та прозапальних цитокінів у хворих із гострою ревматичною лихоманкою та хронічною ревматичною хворобою серця. Український ревматологічний журнал 2010; 3 (41): 9-13.

2. Козар ВВ, Кудря Мя, Устенко НВ, Нікішина ЛЕ, Кравченко СВ. Визначення концентрації метаболітів оксиду азоту в сироватці крові. Лабораторна діагностика 2010; 3 (53): 14-16.

3. Марущак МI. Нітроксидергічні аспекти патогенезугострого ураження легень в експерименті.
Туберкульоз, легеневі хвороби, ВІЛ-інфекція 2011; 3 (6): 69-73.

4. Сапатий АЛ, Купновицька ІГ. Метаболічні особливості оксиду азоту у формуванні ендотеліальної дисфункції за серцево-судинних захворювань. Ліки України 2008; 6 (122): 82-86.

5. Хара МР, Дорохіна АМ. Оксид азоту та серцево-судинна система (огляд літератури). Здобутки клінічної і експериментальної медицини 2010; 1: 14-20.

6. Ячник AI, Гуменюк МI, Чопчик АД. Фізіо- 
логічні аспекти оксиду азоту при порушеннях легеневого кровообігу та роль L - аргініну в корекції його синтезу. Український пульмонологічний журнал 2008; 1: 40-44.

7. Введенская ЛС, Брегель ЛВ, Горбачев ВИ. Изменения в нитроксидергической системе при легечной гипертензии у детей с врожденными пороками сердца. Педиатрия 2006; 2: 21-24.

8. Гарбузенко ДВ. Патофизиологические механизмы и новые направления терапии портальной гипертензии при циррозе печени. Клинич перспективы гастроэнтерол гепатол 2010; 6: 11-20.

9. Денисенко СВ, Костенко ВА. Изменения митохондриального окисления и фосфорилирования в семенниках белых крыс в условиях избыточного поступления в их организм нитрата натрия. Укр биохим журн 2003; 1: 101-103.

10. Ященко ЮБ, Буряк АГ. Нерешенные вопросы использования оксида азота в качестве маркера диагностики и лечебного средства в неонатологии. Современная педиатрия 2010; 4 (32): 97-100.

11. Carter EP, Sato K, Morio Y, McMurtry IF. Inhibition of $\mathrm{K}(\mathrm{Ca})$ channels restores blunted hypoxic pulmonary vasoconstriction in rats with cirrhosis. Am J Physiol Lung Cell Mol Physiol 2000; 279: 903910.

12. Degano $B$, Mittaine $M$, Herve $P$ et al. Nitric oxide production by the alveolar compartment of the lungs in cirrhotic patients. European respiratory Journal 2009; 34(1): 138-144.

13. Delclaux C, Mahut B, Zerah-Lancner F et al. Increased nitric oxide output from alveolar origin during liver cirrhosis versus bronchial source during asthma. Am J Respir Crit Care Med 2002; 165: 332337.

14. European convention for the protection of vertebrate animals used for experimental and other scientific purposes. Council of Europe Strasbourg 1986; 123: 52.
15. Fallon MB, Abrams GA, McGrath JW et al. Common bile duct ligation in the rat: a model of intrapulmonary vasodilatation and hepatopulmonary syndrome. Am J Phisiol 1997; 272: 779-784.

16. Fallon MB. Mechanisms of pulmonary vascular complications of liver disease. Hepatopulmonary syndrome. J Clin Gastroenterol 2005; 39 (2): 138-142.

17. Gomez FP, Barbera JA, Roca J, Burgos F, Gistau C, Rodriguez-Roisin R. Effects of nebulized $\mathrm{N}(\mathrm{G})$-nitro-L-arginine methyl ester in patients with hepatopulmonary syndrome. Hepatology 2006; 43: 1084-1091.

18. Guevara I, Iwanejko J, Dembinska-Kiec A. Determination of nitrite/nitrate in human biologica materia by he simple Griess reaction. Clin Chim Acta 1998; 274 (2): 177-188.

19. Rolla G, Brussino L, Colagrande P. Exhaled nitric oxide and impaired oxygenation in cirrhotic patients before and after liver transplantation. Ann Intern Med 1998; 129: 375-378.

20. Whittle B, Moncada S. Nitric oxide: the elusive mediator of the hyperdynamic circulation of cirrhosis. Hepatology 1992; 16: 1089-1092.

21. Zhang HY, Han DW, Zhao ZF, Liu MS, Wu YJ, Chen XM. Multiple pathogenic factor-induced complications of cirrhosis in rats: A new model of hepatopulmonary syndrome with intestinal endotoxemia. World J Gastroenterology 2007; 13 (25): 3500-3507.

22. Zhang J, Ling Y, Luo B et al. Analysis of pulmonary heme oxygenase- 1 and nitric oxide synthase alterations in experimental hepatopulmonary syndrome. Gastroenterology 2003; 125: 1441-1451.

23. Yaremchuk OZ, Posokhova KA. The liver and kidneys biochemical indices at the experimental pancreatitis in case of the administration of nitric oxide synthesis modulators and recombinant superoxide dismutase. The Ukrainian Biochemical Journal 2011; 83 (4): 57-66. 